\title{
A Rare Case of Blebharitis: Phthiriasis Palpebrarum
}

\section{Nadir Bir Blefarit Nedeni Olgusu: Pitriazis Palpebrarum}

\author{
Fatma Altınsoy (1), Oktay Alver² (D), Selim Doğanay (1) \\ 1'Dünyagöz Hospital, Bursa, Turkey \\ ${ }^{2}$ Department of Medical Microbiology, Uludağ University School of Medicine, Bursa, Turkey
}

Cite this article as: Altınsoy F, Alver O, Doğanay S. A Rare Case of Blebharitis: Phthiriasis Palpebrarum. Turkiye Parazitol Derg 2018; 42:90-2.

\section{ABSTRACT}

A six-year-old male patient was admitted to our hospital due to itching and scalding crusts that persisted 10-15 days in both eyes. Upon biomicroscopic examination, 5-6 semi-translucent, yellowish brown living lice attached to the upper eyelashes and a large number of eggs were observed. Following application of pilocarpine hydrochloride (Pilomann 2\%, Bausch-Lomb) and topical proparacaine hydrochloride (Alcaine $0.5 \%$, Alcon), the paralyzed parasites and eggs were manually removed by pulling with forceps. The lice were identified as adult forms of pubic louse, Pthirus pubis, and its eggs. The patient was treated with pilocarpine hydrochloride, which was applied thrice a day combined with pure vaseline. One week later, no lice or eggs were seen on the eyelashes.

Keywords: Phthiriasis palpebrarum, blepharitis, pilocarpine hydrochloride, vaseline

Received: 07.04.2017

Accepted: 08.01.2018

\section{Öz}

Altı yaşındaki erkek hasta, her iki gözde10-15 gündür devam eden kaşıntı ve çekmekle çıkmayan kabuklar nedeniyle hastanemize başvurdu. Göz muayenesinde; her iki göz üst kapaklarının kirpiklerinde kahverengi kabuklanmalar görüldü. Biyomikroskopik incelemesinde; her iki göz üst kapaklarının kirpiklerine sıkıca tutunmuş, yengeç benzeri hareketli ayakları olan, yarı şeffaf, sarı kahverenkli, 5-6 adet canlı bit ve çok sayıda yumurtaları görüldü. Kirpik diplerine pilokarpin hidroklorid (Pilomann \%2, Bausch-Lomb) damlatıldı. Topikal proparakain hidroklorid (Alcaine $\% 0,5$, Alkon) anestezisini takiben hareketsizleşen bitler ve yumurtaları tutundukları kirpiklerden penset yardımıyla dikkatli bir şekilde alındı. Kirpiklerden alınan örneklerin parazitolojik incelemesinde Pthirus pubis erişkin ve yumurtaları saptandı. Tedavi olarak Pilokarpin hidroklorid (Pilomann \%2, Bausch-Lomb) ile birlikte kirpiklere günde 3 kez sıvı vazelin (petrolatum bileşiği) uygulaması önerildi. Kirpik diplerindeki bit ve yumurtalar bir hafta sonra tamamen ortadan kayboldu.

Anahtar sözcükler: Pitriazis palpebrarum, blefarit, pilokarpin hidroklorid, vazelin

Geliş Tarihi: 07.04.2017

Kabul Tarihi: 08.01.2018

\section{INTRODUCTION}

Human lice are obligatory ectoparasites feeding on blood and humans are their only hosts. There are three types of human lice: the head louse Pediculus humanus capitis; the body louse Pediculus humanus humanus; and the pubic louse Pthirus pubis (1). These parasites cannot fly or jump and are transmitted through direct physical contact between two individuals. Although P. pubis usually involves the pubic/ anal region, it can also infest the axilla, beard area of the face, chest hair, and rarely the eyelashes and eyebrows. Phthiriasis palpebrarum (PP) is a form of parasitosis occurring because of infestation of eyelashes with adult, nymph, and eggs of $P$. pubis, while P. h. capitis and P. h. humanus do not infest eyelashes. $P$. pubis is smaller $(1.3-2 \mathrm{~mm})$ and distinguished from other species by its strong second and third leg pairs. It is less mobile and therefore cannot easily displace itself from the initial contamination area (2). Adult females lay approximately three eggs per day (25-50 eggs during their life span), and the whitish oval eggs are attached

Address for Correspondence / Yazışma Adresi: Oktay Alver E.mail: oktayalver@uludag.edu.tr DOI: $10.5152 /$ tpd.2018.4824 
to the hair on which the lice live (3). The development from egg to egg-laying adult takes from 22 to 27 days. The egg hatches and produces the first nymphal stage, which after three molts develops into nymph 2, nymph 3, and subsequently to either a male or female louse. The incubation period of the egg is 7-8 days. The average adult female lives for 17 days and the male for 22 days (1-3). P. pubis usually infests after puberty and is frequently sexually transmitted. Since transmission is possible with only close contact, the parasite is transferred from the pubic or axillary hair to the eyes by strong physical contact. It should be considered that $P$. pubis infestations can be associated with sexual abuse in children or sexual activity in adolescents (4). PP is a clinical entity that should be considered in the differential diagnosis of blepharitis in all age groups and can be easily missed if only the eye globe is taken into account during biomicroscopic examination and eyelid examination is overlooked.

\section{CASE REPORT}

A six-year-old male patient who was a preschool pupil experienced intense pruritus around the eyes and on his eyelashes for 15-20 days, and a whitish, hard-to-remove crust was observed. There was no hyperemia or irritation in the eyes. Eye examination revealed an intact eye vision. Biomicroscopic examination showed 5-6 semi-translucent, live adult $P$. pubis firmly attached to the upper eyelids with mobile legs resembling those of a crab and eggs attached with a translucent tubular sac surrounding the eyelash (Figure 1).

No hyperemia or follicular reaction on the edge of the eyelid or conjunctiva or other pathology in the anterior and posterior segments of the eye was observed. The family history revealed that he was the only child and lived with his parents. The parents did not complain of any symptoms suggesting pediculosis or phthiriasis. Ophthalmologic examination of the parents did not reveal any parasite in the eyelashes. The family stayed in a boarding house 15-20 days before the crusts and itching in the patient's eyelids appeared. All family members were directed for dermatologic examination to detect potential phthiriasis lesions in other body parts. Ample amount of pilocarpine hydrochloride solution (Pilomann 2\%, Bausch-Lomb) was applied on both the eyes to cause paralysis of $P$. pubis. After five minutes, the movement of the parasites markedly diminished, and they were easily detached from the eyelashes. Following anesthesia by topical proparacaine hydrochloride (Alcaine 0.5\%, Alcon), immobilized parasites and eggs were mechanically removed from the eyelashes with the help of a forceps. The family was advised to clean

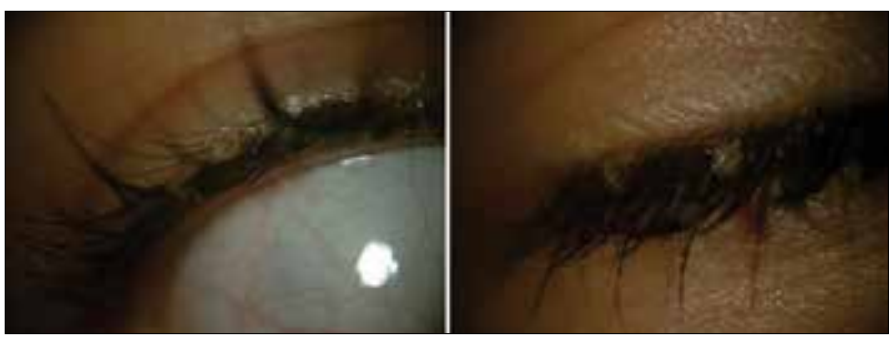

Figure 1. a, b. Slit-lamp examination: Phthiriasis palpebrarum. Mobile louse (a) embedded in the lid skin is seen at the base of the eyelashes and nits (b) attached to the eyelashes visible parasites using pilocarpine hydrochloride drops (Pilomann $2 \%$, Bausch-Lomb) and to apply liquid vaseline on to base of the eyelashes for four days. During the follow-up examination one and two week later, no lice or eggs were observed on the eyelashes. The patient was cautioned during treatment and later on that his clothes and towels should not be shared with the family members.

The study protocol was approved by the Uludag University Human Research Ethics Committee (No: 2015-17/6)

\section{DISCUSSION}

Phthiriasis palpebrarum is a rare eyelid infestation caused by the pubic louse P. pubis, and it can be observed in people who live in crowded places and have poor hygiene (5). PP is a rare condition occurring due to infestation of eyelashes and eyebrows with pubic louse. Eyelashes are the most common site for lice infestation in children (3), and the parasite is acquired from parents through direct contact (6). Brown-reddish granular accumulations on the base of the eyelashes are sufficient for diagnosis, along with the observation of the lice and eggs on the lashes. Screening of the eyelashes and edges of the eyelids during eye examination, with or without marked itching, enables easy diagnosis of contagious parasitosis. The clinical findings of PP include blepharitis accompanied with itching, rash, and edema on the eyelids; follicular conjunctivitis; marginal keratitis; secondary bacterial infections; and rarely eyelid cellulites (7). PP is an uncommon cause of blepharoconjunctivitis. It might be observed as an isolated infestation of the eyelids and can be easily overlooked (8). No hyperemia or conjunctivitis was observed in the present case, while a mild itching was present. Shaving pubic and axillary regions, applying $1 \%$ permethrin shampoo on the infested regions, removing parasites from the eyelashes with a forceps, or cutting the eyelashes, are some of the treatment modalities. There are also studies suggesting that pilocarpine hydrochloride, liquid vaseline, moxifloxacin eye ointment, $1 \%$ mercury oxide, cryotherapy, argon laser (7), topical botulinum toxin application (9), 50\% tea tree oil (10), and single application of $20 \%$ fluorescein on the base of the lashes are effective in the treatment (11). Considering the risk of toxicity with gamma benzene hydrochloride and mercury, 2\% pilocarpine hydrochloride drops and liquid vaseline application seem to be an effective, inexpensive, and easyto-use treatment modality. It should be remembered that pilocarpine hydrochloride does not have any effect on the eggs, and it only paralyzes the parasite. The application of vaseline (petrolatum) along with pilocarpine hydrochloride at the base of the eyelashes 2 to 3 times a day can be considered as an alternative treatment particularly in children as it does not result in eye irritation. The treatment should be continued for 8-10 days, the patient should be reexamined after 7-8 days, and other treatment alternatives should be considered if the given treatment does not provide the appropriate results. It should be remembered that vaseline hinders respiration of the parasite and suffocates it, and it has no fatal effect on the eggs; hence, it might be insufficient for complete eradication. Although there are studies suggesting that ivermectin, an anthelmintic drug, is orally used, its side effects limit its wide- 
spread use. However, it can be used in resistant cases. There is a contribution of a study from Turkey, reporting that eyelid treatment with diluted vinegar can be useful in the treatment of PP through its keratolytic effect (12). Today, the mechanical removal of the eggs is still a treatment option (13). It has been reported in literature that moxifloxacin and mechanical cleaning are practiced and are effective (14). It has also been reported that only $4 \%$ of pilocarpine hydrochloride is effective without mechanical removal (8). The use of fusidic acid, fluorometalon, and tetrazolin drops is reported to be effective after mechanical removal (15). Sundu et al. (16) reported a case of blepharitis related to PP and its treatment using an argon laser. We treated our patient with meticulous application of pilocarpine hydrochloride and liquid petrolatum over the lid margin and eyelashes. We also attempted mechanical removal. It is also important to mention that in addition to treatment, other family members and contact people should be examined and if necessary treated. It should be considered that PP can coexist with other venereal diseases in adult patients, and the possibility of sexual abuse must be investigated, particularly in children. Since it is known that the life span of an adult parasite is less than one month and it cannot survive more than 24-48 hours outside of the human body, clothes and bedding should either kept in air-tight plastic bags for several days, or washed at temperatures above $55^{\circ} \mathrm{C}$. In literature, PP has been reported even in an infant aged nine months (17), and it should be considered for the differential diagnosis in cases of blepharitis, particularly those who are resistant to treatment. Eyelids should be carefully examined under a biomicroscope independently of pruritus, hyperemia, and irritation.

\section{CONCLUSION}

Pthirus pubis infestations do not occur only in people who live in unfavorable and overcrowded conditions with poor hygiene, but is also observed in people with a high socioeconomic status and in all age groups.

Informed Consent: Written informed consent was obtained from patient who participated in this study.

Peer-review: Externally peer-reviewed.

Author Contributions: Concept - A.O., D.S.; Design - A.F., A.O.; Supervision - A.O., D.S.; Resources - A.F., A.O.; Materials - A.F., A.O., D.S.; Data Collection and/or Processing - A.F., A.O.; Analysis and/or Interpretation - A.O., D.S.; Literature Search - A.F., A.O.; Writing Manuscript - A.F., A.O.; Critical Review - A.O., D.S.; Other - A.O., D.S.

Conflict of Interest: No conflict of interest was declared by the authors.

Financial Disclosure: The authors declared that this study has received no financial support.

Hasta Onamı: Yazııı hasta onamı bu çalışmaya katılan hastadan alınmıştır.
Hakem Değerlendirmesi: Dış bağımsız.

Yazar Katkıları: Fikir - A.O., D.S.; Tasarım - A.F., A.O.; Denetleme - A.O., D.S.; Kaynaklar-A.F., A.O.; Malzemeler - A.F., A.O., D.S.; Veri Toplanması ve/veya İşlemesi - A.F., A.O.; Analiz ve/veya Yorum - A.O., D.S.; Literatür Taraması - A.F., A.O.; Yazıyı Yazan - A.F., A.O.; Eleştirel Inceleme - A.O., D.S.; Diğer - A.O., D.S

Çıkar Çatışması: Yazarlar çıkar çatışması bildirmemişlerdir.

Finansal Destek: Yazarlar bu çalışma için finansal destek almadıklarını beyan etmişlerdir.

\section{REFERENCES}

1. Steen CJ, Carnobaro PA, Shwarts RA. Arthropods in dermotology. J Am Acad Dermatol 2004; 50: 819-42. [CrossRef]

2. Nuttall GHF. The biology of Phthirus pubis. Parasitology 1918; 10 : 383-40. [CrossRef]

3. Burgess IF. Human lice and their management. Adv Parasitol 1995; 36: 271-342. [CrossRef]

4. López García JS, García Lozano I, Martínez Garchitorena J. Phthiriasis palpebrarum: diagnosis and treatment. Arch Soc Esp Oftalmol 2003; 78: 365-74. [CrossRef]

5. Alexander JO. Infestation with Anoplura-lice. In: Arthropods and human skin. In: Alexander JO, editor. Berlin: Springer-Verlag 1984; 29-55. [CrossRef]

6. Ikeda N, Nomoto H, Hayasaka S, Nagaki Y. Phthirus pubis infestation of the eyelashes and scalp hairs in a girl. Pediatric Dermatology 2003; 20: 356-7. [CrossRef]

7. Yoon KC, Park HY, Seo MS, Park YG. Mechanıcal treatment of Phthiriasis palpebrarum, Korean J Ophtalmol 2003; 17: 71-3. [CrossRef]

8. Turgut $B$, Kurt J, Catak $O$, Demir T. Phthriasis Palpebrarum Mimicking Lid Eczema and Blepharitis. J Ophthalmol 2009; 803951. [CrossRef]

9. Vaitheeswaran K, Garg S, Kaur P. Botulinum toxin A in the treatment of pthiriasis palpebrarum. J AAPOS 2003; 18: 290-1. [CrossRef]

10. Park IK, Koo H, Chun YSA. Case of Phthiriasis palpebrarum Treated with Tea Tree Oil in a Child. J Korean Ophthalmol Soc 2011; 52: 1222-6. [CrossRef]

11. Mathew M, D'Souza P, Mehta DK. A new treatment of pthiriasis palpebrarum. Ann Ophthalmol 1982; 14: 439-41.

12. Karalezli A, Dursun R, Borazan M, Kucukerdonmez C, Akova YA. Blepharoconjunctivitis Resistant to Routine Blepharitis Theraphy: A Case with Phthiriasis Palpebrarum. Turkiye Klinikleri J Med Sci 2011; 31: 985-8. [CrossRef]

13. Jiang J, Shen T, Hong CY. A peculiar case of eye pruritus: phthiriasis palpebrarum initially misdiagnosed as common blepharitis. Int $\mathrm{J}$ Ophthalmol 2011; 4: 676-7.

14. Ashraf M, Waris A, Kumar A, Akhtar N. A case of unilateral phthiriasis palpebrarum infestation involving the left eye. BMJ Case Rep 2014; DOI: 10.1136/bcr-2013-203307. [CrossRef]

15. Çömez AT, Karada O, Kandemir B, Doğan ÖK. A Rare And Uncommon Cause of Blepharoconjunctıvitıs: Phthırıasıs palpebrarum. Kartal Eğitim ve Araştırma Hastanesi Tıp Dergisi 2007; XVIII: 39-42.

16. Sundu C, Dınc E, Kurtuluş UC, Yıldırım O. Common Blepharitis Related to Phthiriasis Palpebrarum: Argon Laser Phototherapy. Turkiye Parazitol Derg 2015; 39: 252-4. [CrossRef]

17. Keklikci U, Çakmak A. Phthiriasis palpebrarum in an infant. J Pediatr Ophthalmol Strabismus 2009; 46: 173-4. [CrossRef] 